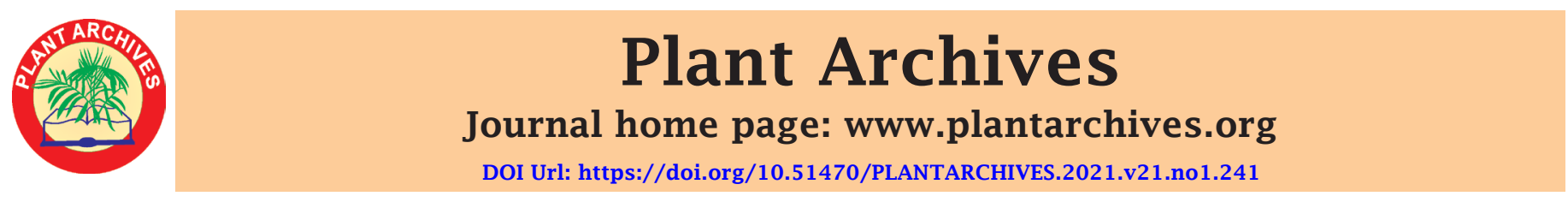

\title{
MACROPHYTIC COMMUNITY AS BIOLOGICAL INDICATORS OF POLLUTION IN ANCHAR LAKE OF KASHMIR
}

\author{
Muzamil Bashir ${ }^{1}$, Javid Ahmad Malik ${ }^{2}$, Asma Zaffar ${ }^{3}$ and Mohammad Farooq Mir \\ Department of Zoology, Central University of Kashmir, Ganderbal Jammu and Kashmir-India \\ Department of Zoology, Guru Ghasidas University, Bilāspur, India \\ Department of Environmental Sciences, University of Kashmir, Srinagar J\&K-India \\ Hydrobiology Research Laboratory S.P. College Srinagar, Cluster University, Srinagar-J\&K-India \\ Email: bmuzamil99@gmail.com \\ (Date of Receiving-26-12-2020; Date of Acceptance-22-03-2021)
}

\begin{abstract}
The most significant biotic constituent in a lake ecosystem is represented by macrophytes in their diverse forms. Macrophytes, because of their capacity to integrate environmental changes over periods of a few years, and reflect the cumulative effects of successive disturbances, are considered excellent indicators of the ecological state of water bodies Macrophytes are by far the most investigated group used for exploring the effects of water level fluctuation on biological organisms in aquatic

ABSTRACT ecosystems. In lake ecosystems, Overall 31 species of aquatic macrophytes were reported from Anchar Lake with different morphology, which consisted of emergent (14), rooted floating leaf type (08), submerged (06) and free floating (03). The efforts mainly focus on the relationships between water level fluctuation and the presence, species richness, distribution and cover of macrophytes.
\end{abstract}

Keywords: Macrophtes, Pollution indicators .co-relation, Anchar Lake.

\section{INTRODUCTION}

\section{Anchar Lake}

The Anchar lake is fluviatile in its origin; shallow basined and is situated $12 \mathrm{kms}$ to the northwest of Srinagar city within the geographical coordinates of $34^{\circ} 20^{\prime}-34^{\circ} 26^{\prime}$ $\mathrm{N}$ latitude and $74^{\circ} 82^{\prime}$ and $74^{\circ} 85^{\prime} \mathrm{E}$ longitude at 1584 m.a.s.l. The lake is mono basined with its main catchment comprising Srinagar city and a number of bordering villages. A network of channels from the river Sind enters the lake on its western shore and serves as the main source of water.

According to Lawrence (1895), the area of the Anchar lake during 1893-1894 was $19.54 \mathrm{~km}^{2}$ and since then there has been a considerable decrease in the surface area of the lake. The area of the lake was $6.5 \mathrm{~km}^{2}$ in the year 2004. As a result of heavy anthropogenic pressures as they use resources of the lake like fishes, nelumbo, trapa etc. without any consideration to the lake ecology, negligence on part of the people as well as by the government. The Anchar lake has shrinked to a large extent in the recent past. With the result the water quality has also deteriorated posed the threat not only to the biotic life of the lake, but also to the humans who reside on the periphery of this lake. During the last one to two decades, human population has expanded manifold in the catchment area of the lake. In addition natural siltation accompanied by anthropogenic siltation has further deteriorated the lake.
During the present investigation the lake was studied for a period of 18 months. The lake was divided into six collection sites on the basis of different types of substratum and ecology of the sites. As such the present lake was divided into six sites shown in map.

\section{Sangam site,}

2. Zinymar site,

3. Centre site,

4. Skims hospital site,

5. Eid-gah site,

6. Jinab shab shrine site.

\section{Macrophytes}

Aquatic vegetation supports critical ecological services by providing the habitat for a diverse and economically important faunal community, sequestering carbon and nutrients, stabilizing sediment and shorelines (Ortho et al., 2006; Carr et al., 2010; Duarte et al., 2005). In addition, aquatic vegetation is a biological indicator or sentinel of water quality and ecological value in aquatic ecosystems (Ortho, 2006; Søndergaard et al., 2010). Unfortunately, the aquatic vegetation of lake ecosystems has undergone substantial degradation with the onrushing advance of human settlement and water resources exploitation throughout the world in past decades (Orth et al., 2006; Hicks \& Frost., 2011; Waycott et al., 2009; Brescian et al., 2012; Azzella et al., 2014). For example, a study over the past 100 years in shallow lakes showed that the majority of lakes have lost all or most of their 
macrophyte taxa. These changes have largely been attributed to eutrophication caused by increasing nutrients and sediments from the alteration of the surrounding catchments and their subsequent effects on water quality, increased phytoplankton, hypoxia, and anoxia in surficial sediments (Scheffer et al., 2001; Waycott et al., 2009; Krause-Jensen et al., 2008). In addition, habitat alteration due to reclamation, dredging and filling, aquaculture, and alien species invasion has also contributed to the decline of native aquatic vegetation species (Qin et al., 2007; Villamagna et al., 2010; Qin, 2008; Schallenberg \& Sorrell, 2009).

In aquatic habitat, plant species of different groups serve as reliable indices for biological monitoring of pollution load. The aquatic vascular plants are potentially useful as indicators of water status. By their ability to accumulate toxic substances, they indicate their presence in the environment even if they are present in very low concentrations. In many sensitive species metal induced morphological and structural changes may also be indicative of changes which are specific to some metals. The nutrient enrichment effect is indicated by the disappearance of susceptible species leading to the change of species composition. These may be successfully used as ecological indicators (bioindicators) for assessing and predicting environmental changes.

\section{MATERIALS AND METHODS}

Ten water samples were collected in triplicate using a clean sample container. Those samplings were accomplished within the targeted period in order to protect the nutrients inside. The samples were examined within 30 days as it kept frozen below $-20^{\circ} \mathrm{C}$. Preservation of samples was done by the addition of $2.5 \mathrm{ml}$ chloroform in $500 \mathrm{ml}$ of water for further analysis. They were filtered before proceed to the next stage of nutrients analyzing. DR 2800 Spectrophotometer was used to detect different study nutrients which are nitrite $\left(\mathrm{NO}_{2}-\mathrm{N}\right)$, nitrate $\left(\mathrm{NO}_{3}-\mathrm{N}\right)$ and phosphate $\left(\mathrm{PO}_{4}^{-3}\right)$. All representative values were displayed by mean value and standard deviation. Physicochemical analysis was done on site using the YSI 5556 MPS (Multiprobe system). The measured parameters are dissolved oxygen (DO) in $\mathrm{mg} / \mathrm{L}, \mathrm{pH}$, salinity in $\mathrm{ppt}$, conductivity in $\mu \mathrm{S} / \mathrm{cm}$ and total dissolved solids (TDS) in $\mathrm{mg} / \mathrm{L}$.

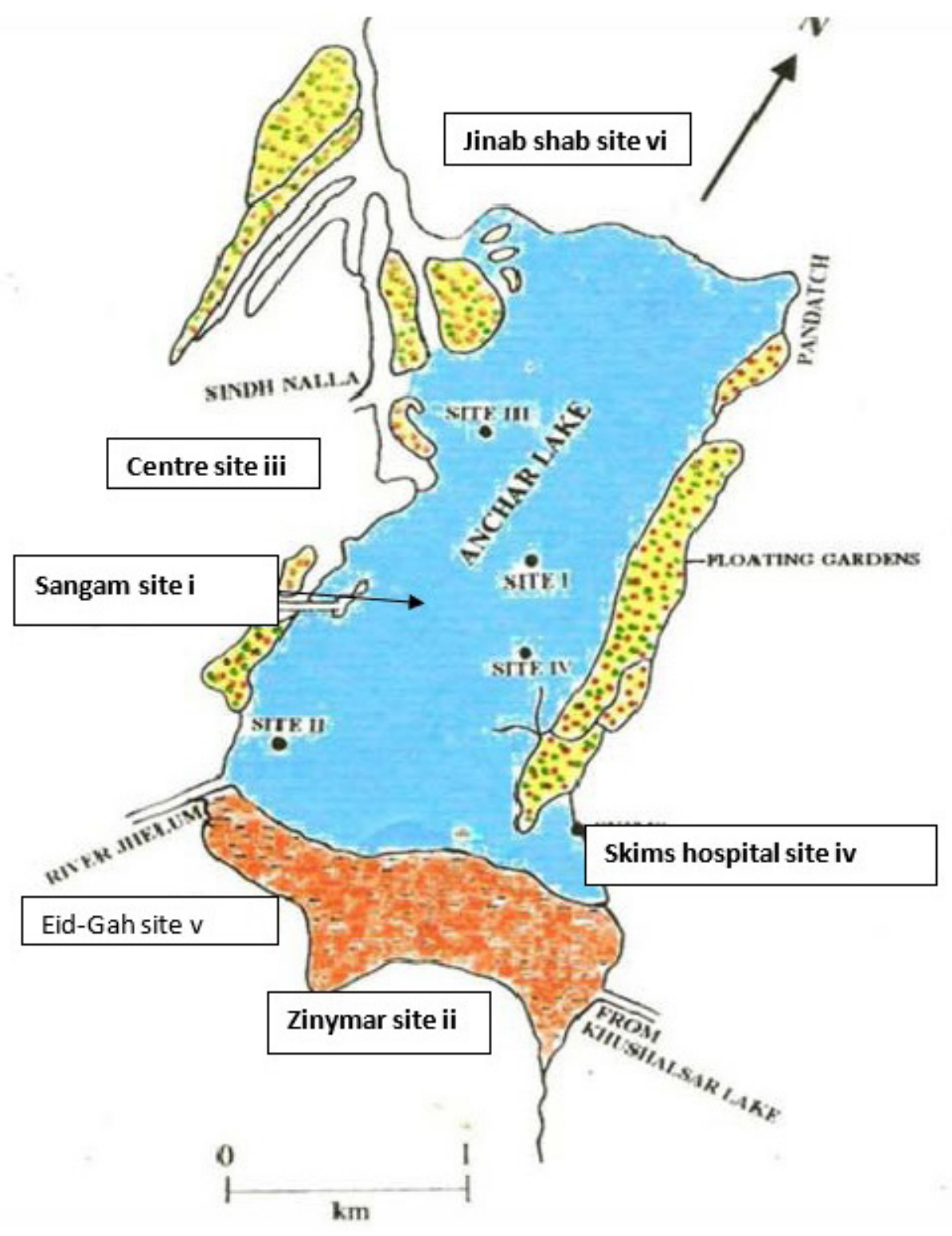




\section{Ecological status Macrophyte indexe (ESMI)}

Base on the gathered data, the Ecological Status Macrophyte Index (ESMI) was calculated to assess the ecological state of the lake. The ESMI index meets all requirements of the Water Framework Directive imposed on quality indicators for assessing the ecological state of a water body. It is calculated based on the following formula:

$\mathrm{ESMI}=1-\exp \left[-\mathrm{H}^{-} \mathrm{H}_{\max } \times \mathrm{Z} \times \exp (\mathrm{N} / \mathrm{P})\right]$

ESMI is based on the Shannon-Weaver diversity index $(\mathrm{H})$.which was adopted as an indicator of taxonomic composition.

$\mathrm{H}=-\Sigma \mathrm{ni} / \mathrm{N} \mathrm{x} \ln (\mathrm{ni} / \mathrm{N})$

where:

H - Shannon-Weaver diversity index

ni -Area covered by given plant association expressed as a percentage of total phytolittoral surface area

N-Total surface area of plant association (100\%)

The structural simplification of plant systems due to anthropological pressure is measured by the ratio of actual Shannon-Weaver diversity $(\mathrm{H})$ to the theoretically possible maximum diversity $\left(\mathrm{H}_{\max }\right)$, calculated based on the following formula:

$\mathrm{H}_{\max }=\ln \mathrm{S}$

where:

$\mathrm{H}_{\max }$ - Index of theoretical maximum Shannon-Weaver diversity

S - Number of plant association in the phytolittoral

The colonization index $(\mathrm{Z})$ is the ratio of the actual surface area occupied by macrophytes to the surface area potentially available to plants. In Polish methodology, for a lake to represent at least a good ecological state, the phytolittoral surface area should not be less than the area limited by the 2.5 isobath. which corresponds to a maximum plant depth of $2.5 \mathrm{~m}$. The colonization index is calculated based on the following formula:

$\mathrm{Z}=\mathrm{N} / 2.5 \mathrm{Isob}$

where:

Z-Colonization index

$\mathrm{N}$ - Total phytolittoral surface area (ha);
2.5 isob. - Phytolittoral surface area limited by the 2.5 isobath

(ha)

The index takes on values within the range of 0 to 1 , where the maximum value indicates a reference state and it decreases with deterioration in ecosystem quality. Moreover, these values are interpreted to the ecological state of lake.

\section{Macrophyte River Index (MRI)}

The MRI that is necessary to estimate the ecological status according to the European Water Framework Directive was calculated using the formula:

MRI $=[\Sigma($ Li $\times$ Wi $\times$ Pi $) / \Sigma($ Wi $\times$ Pi $)] \times 10$

where:

$\mathrm{Li}$ - Indicator value of the species,

Wi - Weight coefficient of the species,

Pi - Cover coefficient of the species, according to the gradual scale.

\section{RESULTS AND DISCUSSION}

The linkage of macrophyte abundance with the pollution status of different sites of the Anchar Lake was documented by the ' $\mathrm{r}$ ' value for nitrate $\left(\mathrm{NO}_{3}\right)$, phosphate $\left(\mathrm{PO}_{4}\right)$ and Ammonical nitrogen $\left(\mathrm{NH}_{3} \mathrm{H}\right)$. Overall 31 species of aquatic macrophytes were reported from Anchar Lake with different morphology, which consisted of emergent (14), rooted floating leaf type (08), submerged (06) and free floating (03).

The diversity indices and correlation matrix of macrophytes at site 1 is presented in table 1 . It is evident from the table that among emergent macrophytes, Phragmites australis $\left(R_{c}=0.11 ; R_{s}=0.89 ; S=0.459 ; C_{i}=0.541\right)$ and Typha angustata $\left(R_{c}=0.12 ; R_{s}=0.92 ; S=0.462 ; C_{i}=0.538\right)$ were dominant. All the emergent plant varieties showed positive correlation with nitrate $(\mathrm{r}=0.838)$, phosphate $(\mathrm{r}$ $=0.812)$ and Ammonical nitrogen $(\mathrm{r}=0.882)$. Among rooted floating leaf type macrophytes, Nelumbo nucifera $\left(R_{c}=0.13 ; R_{s}=0.89 ; S=0.425 ; C_{i}=0.575\right) ;$ Nymphea maxicana $\left(R_{c}=0.11 ; R_{s}=0.99 ; S=0.415 ; C_{i}=0.585\right)$; Nymphea peltatum $\left(R_{c}=0.15 ; R_{s}=0.95 ; S=0.415 ; C_{i}=\right.$ $0.585)$, and Trapa natans $\left(R_{c}=0.12 ; R_{s}=0.92 ; S=0.440\right.$; $\left.C_{i}=0.56\right)$ were dominant. All the rooted floating leaf type plant varieties showed positive correlation with nitrate $(\mathrm{r}$ $=0.999)$, phosphate $(\mathrm{r}=0.892)$ and Ammonical nitrogen $(\mathrm{r}=0.902)$.

Similarly among submerged macrophytes, Ceratophyllum demersum $\left(R_{c}=0.11 ; R_{s}=0.86 ; S=0.414 ; C_{i}=0.586\right)$; 
Hydrilla verticillata $\left(R_{c}=0.12 ; R_{s}=0.89 ; S=0.452 ; C_{i}=\right.$ $0.548)$; and Myropphyllum spicatum $\left(R_{c}=0.11 ; R_{s}=0.88\right.$; $\left.S=0.425 ; C_{i}=0.575\right)$ were dominant. All the submerged plant varieties showed positive correlation with nitrate ( $\mathrm{r}$ $=0.912)$, phosphate $(\mathrm{r}=0.922)$ and Ammonical nitrogen $(\mathrm{r}=0.999)$. Likewise, among free floating macrophytes, Azolla pinnata $\left(R_{c}=0.08 ; R_{s}=0.82 ; S=0.426 ; C_{i}=\right.$ $0.574) ;$ Lemna spp. $\left(R_{c}=0.09 ; R_{s}=0.81 ; S=0.442 ; C_{i}\right.$ $=0.558)$; and Salvinia natans $\left(R_{c}=0.09 ; R_{s}=0.85 ; S=\right.$ $\left.0.415 ; C_{i}=0.585\right)$ were dominant. All the free floating plant varieties showed positive correlation with nitrate $(\mathrm{r}=$ 0.989), phosphate $(r=0.988)$ and Ammonical nitrogen $(r$ $=0.988$ ). The strong positive correlation with the chemical constituents of water indicate the highest pollution status of Anchar lake with ESMI of 0.08 and MRI value of 3.9. The diversity indices and correlation matrix of macrophytes at site 2 is presented in table 2 . It is evident from the table that among emergent macrophytes, Phragmites australis $\left(R_{c}=0.12 ; R_{s}=1.06 ; S=0.425 ; C_{i}=0.575\right)$ and Typha angustata $\left(R_{c}=0.11 ; R_{s}=0.99 ; S=0.452 ; C_{i}=0.548\right)$ were dominant. All the emergent plant varieties showed positive correlation with nitrate $(\mathrm{r}=0.982)$, phosphate $(\mathrm{r}$ $=0.992)$ and Ammonical nitrogen $(\mathrm{r}=0.990)$. Among rooted floating leaf type macrophytes, Nelumbo nucifera $\left(R_{c}=0.14 ; R_{s}=1.01 ; S=0.453 ; C_{i}=0.547\right) ;$ Nymphea maxicana $\left(R_{c}=0.12 ; R_{s}=1.01 ; S=0.456 ; C_{i}=0.544\right)$; Nymphea peltatum $\left(R_{c}=0.13 ; R_{s}=0.98 ; S=0.458 ; C_{i}\right.$ $=0.542)$, and Trapa natans $\left(R_{c}=0.12 ; R_{s}=0.99 ; S=\right.$ $\left.0.452 ; C_{i}=0.548\right)$ were dominant. All the rooted floating leaf type plant varieties showed positive correlation with nitrate $(\mathrm{r}=0.982)$, phosphate $(\mathrm{r}=0.952)$ and Ammonical nitrogen $(r=0.968)$.

Similarly among submerged macrophytes, Ceratophyllum demersum $\left(R_{c}=0.12 ; R_{s}=1.02 ; S=0.415 ; C_{i}=0.585\right)$; Hydrilla verticillata $\left(R_{c}=0.12 ; R_{s}=1.01 ; S=0.419 ; C_{i}=\right.$ $0.581)$; and Myropphyllum spicatum $\left(R_{c}=0.12 ; R_{s}=1.02\right.$; $\left.S=0.429 ; C_{i}=0.571\right)$ were dominant. All the submerged plant varieties showed positive correlation with nitrate $(\mathrm{r}$ $=0.926)$, phosphate $(r=0.982)$ and Ammonical nitrogen $(\mathrm{r}=0.995)$. Likewise, among free floating macrophytes, Azolla pinnata $\left(R_{c}=0.12 ; R_{s}=0.98 ; S=0.452 ; C_{i}=\right.$ $0.548)$; Lemna spp. $\left(R_{c}=0.13 ; R_{s}=0.86 ; S=0.438 ; C_{i}\right.$ $=0.562)$; and Salvinia natans $\left(R_{c}=0.12 ; R_{s}=0.92 ; S=\right.$ $\left.0.438 ; C_{i}=0.562\right)$ were dominant. All the free floating plant varieties showed positive correlation with nitrate $(\mathrm{r}=$ 0.865), phosphate $(r=0.899)$ and Ammonical nitrogen ( $\mathrm{r}$ $=0.999$ ). The strong positive correlation with the chemical constituents of water indicate the highest pollution status of Anchar lake with ESMI of 0.09 and MRI value of 4.2.

In case of site 3 , it is evident from the table 3 that among emergent macrophytes, Phragmites australis $\left(R_{c}=0.29 ; R_{s}=1.08 ; S=0.415 ; C_{i}=0.585\right)$ and Typha angustata $\left(R_{c}=0.33 ; R_{s}=1.09 ; S=0.425 ; C_{i}=0.575\right)$ were dominant. All the emergent plant varieties showed positive correlation with nitrate $(\mathrm{r}=0.821)$, phosphate $(\mathrm{r}$ $=0.881)$ and Ammonical nitrogen $(\mathrm{r}=0.812)$. Among rooted floating leaf type macrophytes, Nelumbo nucifera $\left(R_{c}=0.25 ; R_{s}=1.05 ; S=0.439 ; C_{i}=0.561\right) ;$ Nymphea maxicana $\left(R_{c}^{s}=0.29 ; R_{s}=1.12 ; S=0.452 ; C_{i}=0.548\right)$; Nymphea peltatum $\left(R_{c}=0.20 ; R_{s}=1.15 ; S=0.452 ; C_{i}\right.$ $=0.548)$, and Trapa natans $\left(R_{c}=0.26 ; R_{s}=1.16 ; S=\right.$ $\left.0.459 ; C_{i}=0.541\right)$ were dominant. All the rooted floating leaf type plant varieties showed positive correlation with nitrate $(\mathrm{r}=0.756)$, phosphate $(\mathrm{r}=0.815)$ and Ammonical nitrogen $(r=0.886)$.

Similarly among submerged macrophytes, Ceratophyllum demersum $\left(R_{c}=0.19 ; R_{s}=1.17 ; S=0.459 ; C_{i}=0.541\right)$; Hydrilla verticillata $\left(R_{c}=0.20 ; R_{s}=1.16 ; S=0.455 ; C_{i}=\right.$ $0.545)$; and Myropphyllum spicatum $\left(R_{c}=0.22 ; R_{s}=1.18\right.$; $\left.S=0.429 ; C_{i}=0.571\right)$ were dominant. All the submerged plant varieties showed positive correlation with nitrate ( $\mathrm{r}$ $=0.902)$, phosphate $(\mathrm{r}=0.847)$ and Ammonical nitrogen $(\mathrm{r}=0.881)$. Likewise, among free floating macrophytes, Azolla pinnata $\left(R_{c}=0.26 ; R_{s}=1.12 ; S=0.436 ; C_{i}=\right.$ $0.564) ;$ Lemna spp. $\left(R_{c}=0.27 ; R_{s}=1.12 ; S=0.436 ; C_{i}\right.$ $=0.564)$; and Salvinia natans $\left(R_{c}=0.26 ; R_{s}=1.15 ; S=\right.$ $\left.0.449 ; C_{i}=0.551\right)$ were dominant. All the free floating plant varieties showed positive correlation with nitrate $(\mathrm{r}=$ $0.869)$, phosphate $(\mathrm{r}=0.712)$ and Ammonical nitrogen $(\mathrm{r}$ $=0.849$ ). The strong positive correlation with the chemical constituents of water indicate the highest pollution status of Anchar lake with ESMI of 0.102 and MRI value of 4.2. In case of site 4 , it is evident from the table 4 that among emergent macrophytes, Phragmites australis $\left(R_{c}=0.44 ; R_{s}=1.25 ; S=0.498 ; C_{i}=0.502\right)$ and Typha angustata $\left(R_{c}=0.42 ; R_{s}=1.45 ; S=0.501 ; C_{i}=0.499\right)$ were dominant. All the emergent plant varieties showed positive correlation with nitrate $(\mathrm{r}=0.596)$, phosphate $(\mathrm{r}$ $=0.589)$ and Ammonical nitrogen $(\mathrm{r}=0.845)$. Among rooted floating leaf type macrophytes, Nelumbo nucifera $\left(R_{c}=0.35 ; R_{s}=1.39 ; S=0.498 ; C_{i}=0.502\right)$; Nymphea maxicana $\left(R_{c}=0.33 ; R_{s}=1.42 ; S=0.501 ; C_{i}=0.499\right)$; Nymphea peltatum $\left(R_{c}=0.31 ; R_{s}=1.41 ; S=0.502 ; C_{i}\right.$ $=0.498)$, and Trapa natans $\left(R_{c}=0.32 ; R_{s}=1.46 ; S=\right.$ $\left.0.502 ; C_{i}=0.498\right)$ were dominant. All the rooted floating leaf type plant varieties showed positive correlation with nitrate $(\mathrm{r}=0.785)$, phosphate $(\mathrm{r}=0.748)$ and Ammonical nitrogen $(r=0.869)$.

Similarly among submerged macrophytes, Ceratophyllum demersum $\left(R_{c}=0.22 ; R_{s}=1.58 ; S=0.512 ; C_{i}=0.488\right)$; Hydrilla verticillata $\left(R_{c}=0.25 ; R_{s}=1.59 ; S=0.511 ; C_{i}=\right.$ $0.489)$; and Myropphyllum spicatum $\left(R_{c}=0.30 ; R_{s}=1.58\right.$; $\left.S=0.503 ; C_{i}=0.497\right)$ were dominant. All the submerged plant varieties showed positive correlation with nitrate $(\mathrm{r}$ $=0.891)$, phosphate $(\mathrm{r}=0.912)$ and Ammonical nitrogen $(\mathrm{r}=0.855)$. Likewise, among free floating macrophytes, Azolla pinnata $\left(R_{c}=0.32 ; R_{s}=1.58 ; S=0.506 ; C_{i}=\right.$ $0.494) ;$ Lemna spp. $\left(R_{c}=0.35 ; R_{s}=1.57 ; S=0.509 ; C_{i}\right.$ $=0.491)$; and Salvinia natans $\left(R_{c}=0.35 ; R_{s}=1.56 ; S=\right.$ 0.509; $\left.C_{i}=0.491\right)$ were dominant. All the free floating plant varieties showed positive correlation with nitrate $(\mathrm{r}=0.891)$, phosphate $(\mathrm{r}=0.912)$ and Ammonical 
Table 1: Macrophyte based pollution correlation at site 1 in Anchar Lake

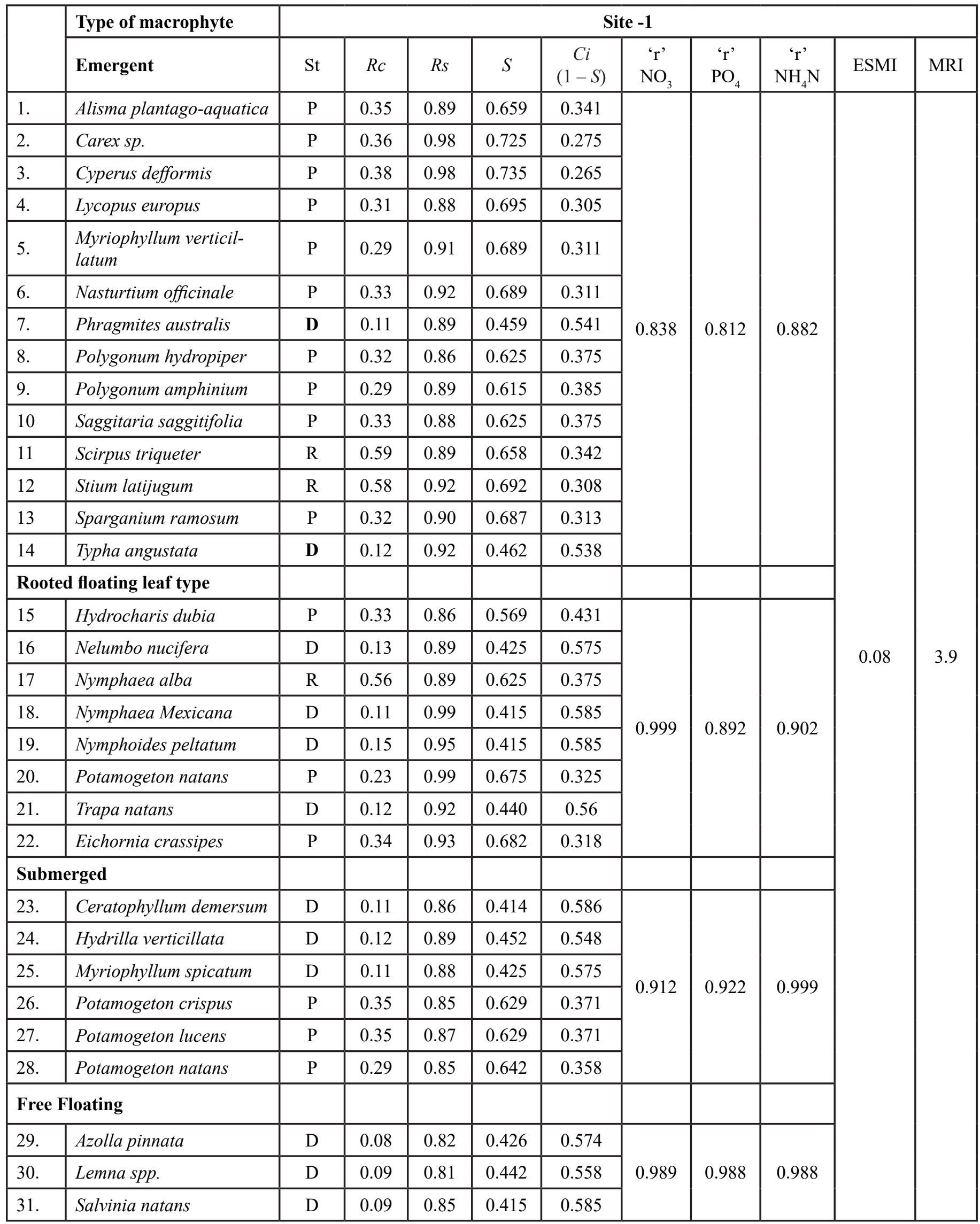

$-R_{s}$ as a measure of species competition

- $R_{\mathrm{c}}$ as a measure of the species composition

- $\mathrm{S}$ as an index combining quantity and quality of vegetation

- ESMI-Ecological status Macrophyte indexe

- MRI - Macrophyte River Index

- 'r' - Correlation Coefficient 
Table 2: Macrophyte based pollution correlation at site 2 in Anchar Lake

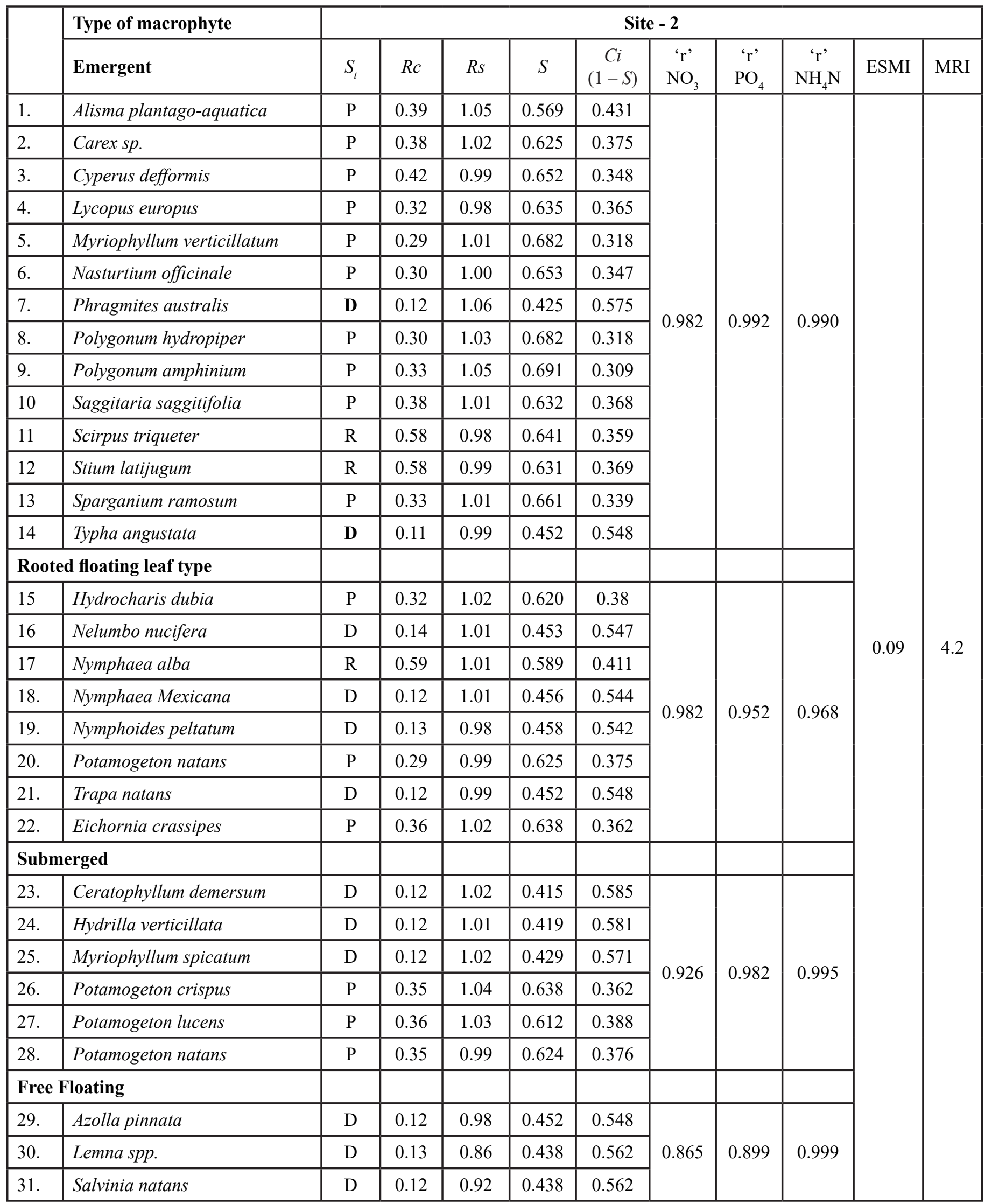

$-R_{s}$ as a measure of species competition

$-R_{\mathrm{c}}$ as a measure of the species composition

$-\mathrm{S}$ as an index combining quantity and quality of vegetation

- ESMI-Ecological status Macrophyte indexe

- MRI - Macrophyte River Index

- ' $r$ ' - Correlation Coefficient 
Table 3: Macrophyte based pollution correlation at site 3 in Anchar Lake

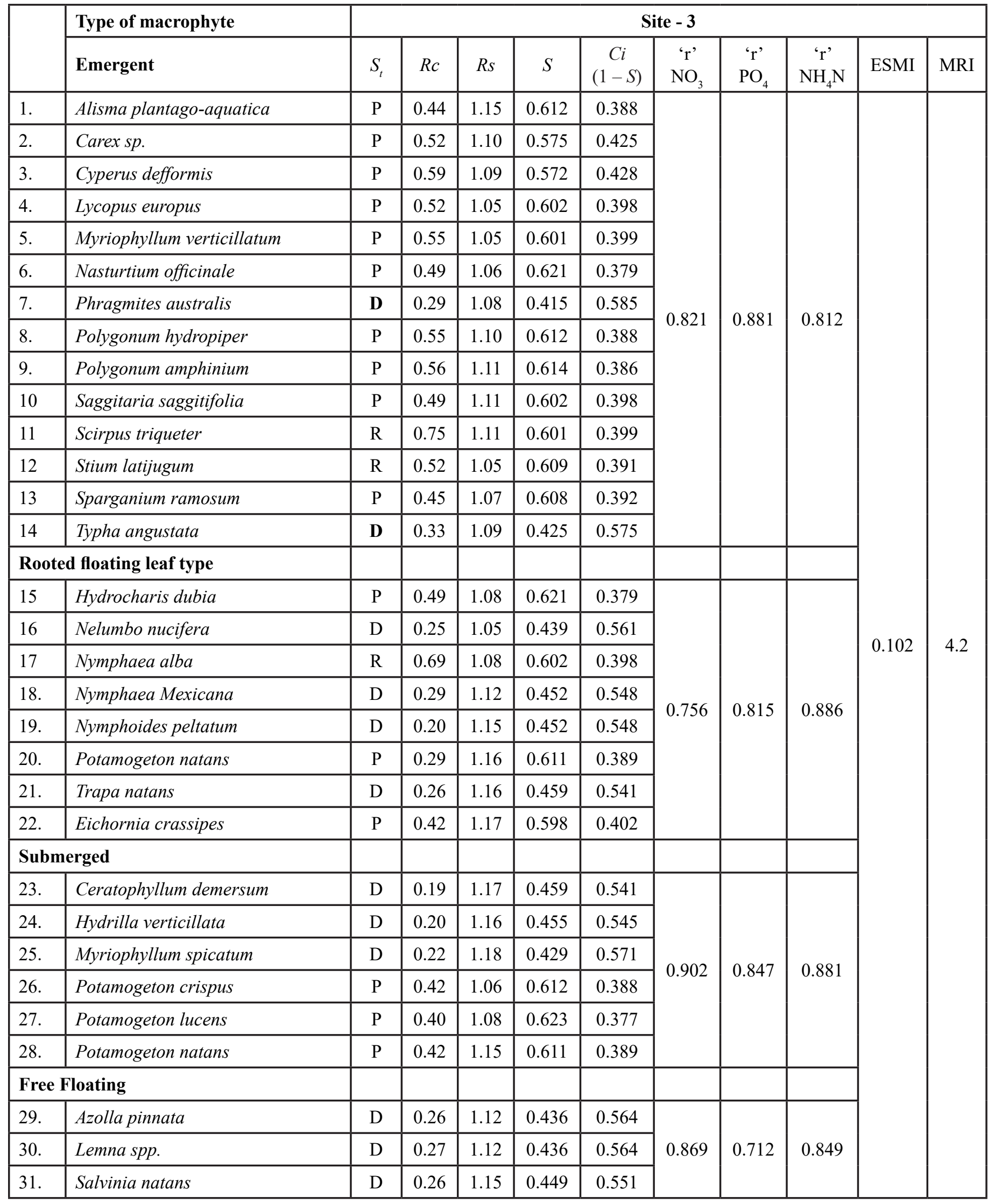

$-R_{s}$ as a measure of species competition

$-R_{\mathrm{c}}$ as a measure of the species composition

$-\mathrm{S}$ as an index combining quantity and quality of vegetation

- ESMI-Ecological status Macrophyte indexe

- MRI - Macrophyte River Index

- ' $r$ ' - Correlation Coefficient 
Table 4: Macrophyte based pollution correlation at site 4 in Anchar Lake

\begin{tabular}{|c|c|c|c|c|c|c|c|c|c|c|c|}
\hline & Type of macrophyte & & & & & & $e-4$ & & & & \\
\hline & Emergent & St & $R c$ & $R s$ & $S$ & $\begin{array}{c}C i \\
(1-S)\end{array}$ & $\begin{array}{c}\text { 'r' } \\
\mathrm{NO}_{3}\end{array}$ & $\begin{array}{c}' r ' \\
\mathrm{PO}_{4}\end{array}$ & $\begin{array}{c}\text { 'r' } \\
\mathrm{NH}_{4} \mathrm{~N}\end{array}$ & ESMI & MRI \\
\hline 1. & Alisma plantago-aquatica & $\mathrm{P}$ & 0.59 & 1.32 & 0.689 & 0.311 & \multirow{14}{*}{0.596} & \multirow{14}{*}{0.589} & \multirow{14}{*}{0.845} & \multirow{34}{*}{0.106} & \multirow{34}{*}{14.89} \\
\hline 2. & Carex sp. & $\mathrm{P}$ & 0.58 & 1.35 & 0.689 & 0.311 & & & & & \\
\hline 3. & Cyperus defformis & $\mathrm{P}$ & 0.61 & 1.29 & 0.689 & 0.311 & & & & & \\
\hline 4. & Lycopus europus & $\mathrm{P}$ & 0.61 & 1.25 & 0.687 & 0.313 & & & & & \\
\hline 5. & Myriophyllum verticillatum & $\mathrm{P}$ & 0.58 & 1.25 & 0.687 & 0.313 & & & & & \\
\hline 6. & Nasturtium officinale & $\mathrm{P}$ & 0.54 & 1.27 & 0.688 & 0.312 & & & & & \\
\hline 7. & Phragmites australis & D & 0.44 & 1.25 & 0.498 & 0.502 & & & & & \\
\hline 8. & Polygonum hydropiper & $\mathrm{P}$ & 0.58 & 1.23 & 0.659 & 0.341 & & & & & \\
\hline 9. & Polygonum amphinium & $\mathrm{P}$ & 0.52 & 1.21 & 0.658 & 0.342 & & & & & \\
\hline 10 & Saggitaria saggitifolia & $\mathrm{P}$ & 0.55 & 1.37 & 0.698 & 0.302 & & & & & \\
\hline 11 & Scirpus triqueter & $\mathrm{R}$ & 0.78 & 1.35 & 0.702 & 0.298 & & & & & \\
\hline 12 & Stium latijugum & $\mathrm{R}$ & 0.58 & 1.30 & 0.701 & 0.299 & & & & & \\
\hline 13 & Sparganium ramosum & $\mathrm{P}$ & 0.58 & 1.39 & 0.702 & 0.298 & & & & & \\
\hline 14 & Typha angustata & D & 0.42 & 1.45 & 0.501 & 0.499 & & & & & \\
\hline \multicolumn{2}{|c|}{ Rooted floating leaf type } & & & & & & & & & & \\
\hline 15 & Hydrocharis dubia & $\mathrm{P}$ & 0.52 & 1.42 & 0.682 & 0.318 & \multirow{8}{*}{0.785} & \multirow{8}{*}{0.748} & \multirow{8}{*}{0.869} & & \\
\hline 16 & Nelumbo nucifera & $\mathrm{D}$ & 0.35 & 1.39 & 0.498 & 0.502 & & & & & \\
\hline 17 & Nymphaea alba & $\mathrm{R}$ & 0.73 & 1.38 & 0.609 & 0.391 & & & & & \\
\hline 18. & Nymphaea Mexicana & $\mathrm{D}$ & 0.33 & 1.42 & 0.501 & 0.499 & & & & & \\
\hline 19. & Nymphoides peltatum & $\mathrm{D}$ & 0.31 & 1.41 & 0.502 & 0.498 & & & & & \\
\hline 20. & Potamogeton natans & $\mathrm{P}$ & 0.42 & 1.40 & 0.701 & 0.299 & & & & & \\
\hline 21. & Trapa natans & $\mathrm{D}$ & 0.32 & 1.46 & 0.502 & 0.498 & & & & & \\
\hline 22. & Eichornia crassipes & $\mathrm{P}$ & 0.49 & 1.52 & 0.701 & 0.299 & & & & & \\
\hline \multicolumn{2}{|c|}{ Submerged } & & & & & & & & & & \\
\hline 23. & Ceratophyllum demersum & $\mathrm{D}$ & 0.22 & 1.58 & 0.512 & 0.488 & \multirow{6}{*}{0.891} & \multirow{6}{*}{0.912} & \multirow{6}{*}{0.855} & & \\
\hline 24. & Hydrilla verticillata & $\mathrm{D}$ & 0.25 & 1.59 & 0.511 & 0.489 & & & & & \\
\hline 25. & Myriophyllum spicatum & $\mathrm{D}$ & 0.30 & 1.58 & 0.503 & 0.497 & & & & & \\
\hline 26. & Potamogeton crispus & $\mathrm{P}$ & 0.49 & 1.52 & 0.703 & 0.297 & & & & & \\
\hline 27. & Potamogeton lucens & $\mathrm{P}$ & 0.46 & 1.49 & 0.689 & 0.311 & & & & & \\
\hline 28. & Potamogeton natans & $\mathrm{P}$ & 0.49 & 1.56 & 0.698 & 0.302 & & & & & \\
\hline \multicolumn{2}{|c|}{ Free Floating } & & & & & & & & & & \\
\hline 29. & Azolla pinnata & $\mathrm{D}$ & 0.32 & 1.58 & 0.506 & 0.494 & \multirow{3}{*}{0.921} & \multirow{3}{*}{0.842} & \multirow{3}{*}{0.729} & & \\
\hline 30. & Lemna spp. & $\mathrm{D}$ & 0.35 & 1.57 & 0.509 & 0.491 & & & & & \\
\hline 31. & Salvinia natans & $\mathrm{D}$ & 0.35 & 1.56 & 0.509 & 0.491 & & & & & \\
\hline
\end{tabular}

$-R_{s}$ as a measure of species competition

$-R_{\mathrm{c}}$ as a measure of the species composition

$-\mathrm{S}$ as an index combining quantity and quality of vegetation

- ESMI-Ecological status Macrophyte indexe

- MRI - Macrophyte River Index

- ' $r$ ' - Correlation Coefficient 
Table 5: Macrophyte based pollution correlation at site 5 in Anchar Lake

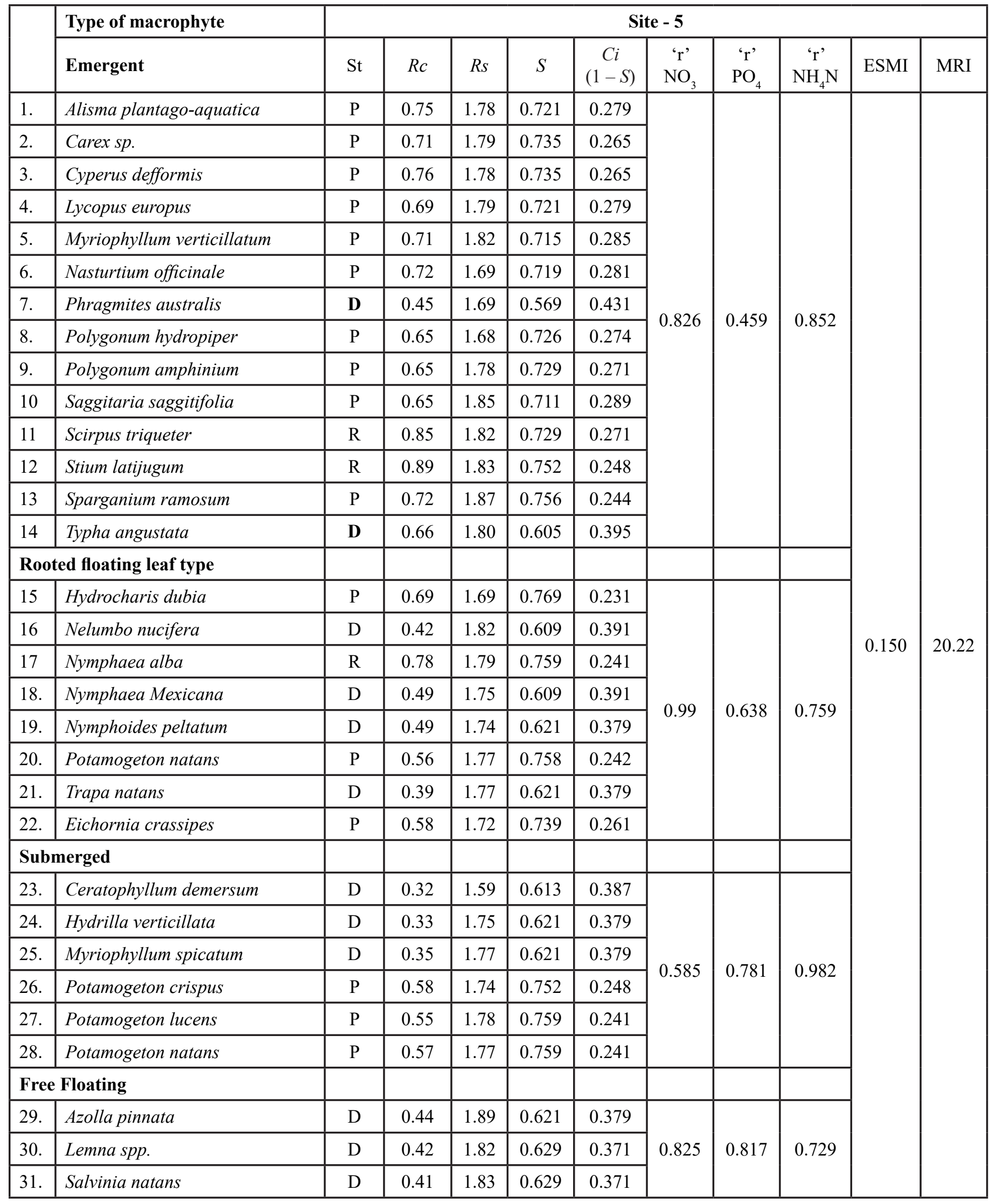

- $R_{s}$ as a measure of species competition

$-R_{\mathrm{c}}$ as a measure of the species composition

$-\mathrm{S}$ as an index combining quantity and quality of vegetation

- ESMI-Ecological status Macrophyte indexe

- MRI - Macrophyte River Index

- ' $r$ ' - Correlation Coefficient 
Table 6: Macrophyte based pollution correlation at site 6 in Anchar Lake

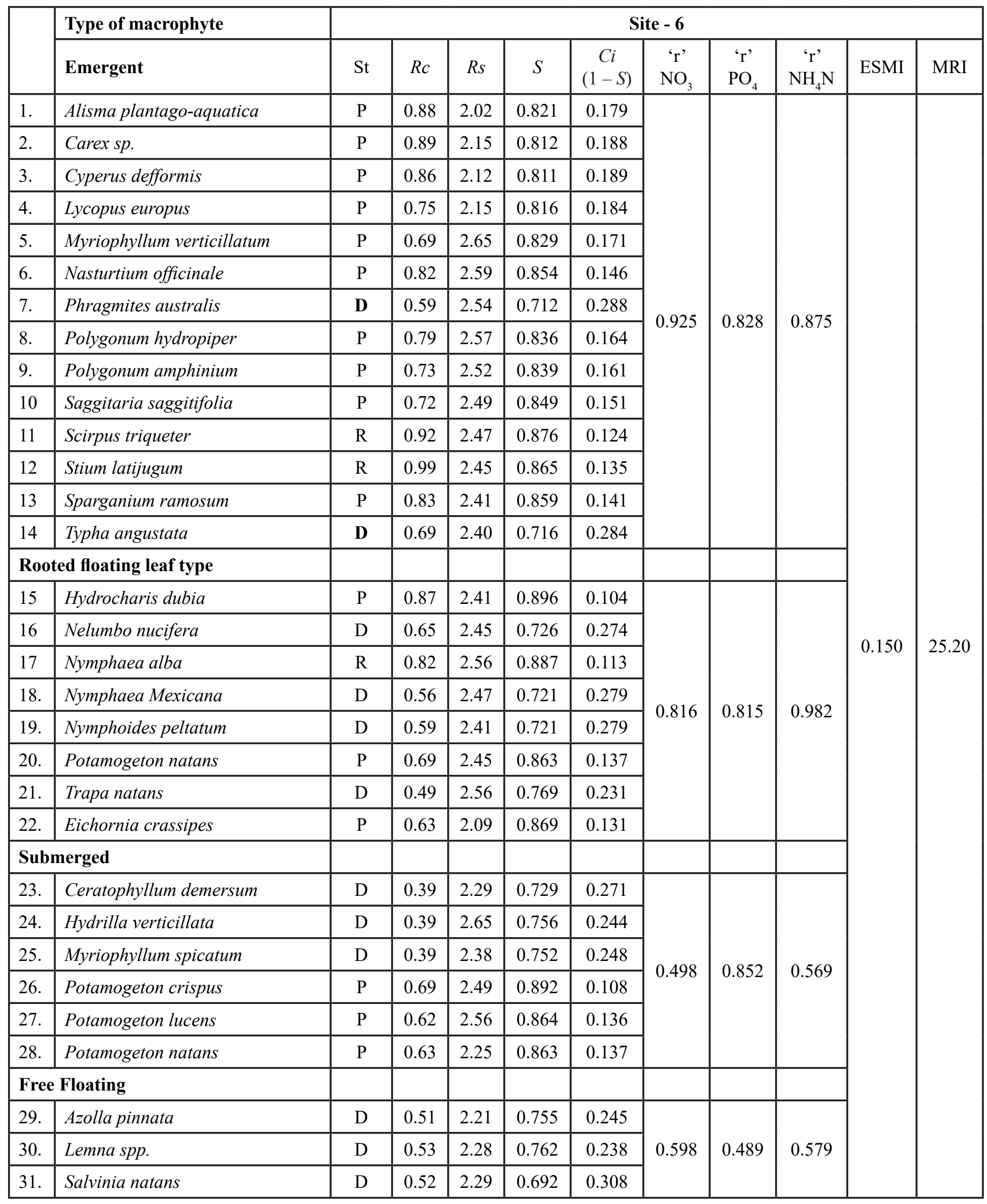

- $R_{s}$ as a measure of species competition

$-R_{\mathrm{c}}$ as a measure of the species composition

$-\mathrm{S}$ as an index combining quantity and quality of vegetation

- ESMI-Ecological status Macrophyte indexe

- MRI - Macrophyte River Index

- ' $r$ ' - Correlation Coefficient 
nitrogen $(\mathrm{r}=0.855)$. The strong positive correlation with the chemical constituents of water indicate the highest pollution status of Anchar lake with ESMI of 0.106 and MRI value of 14.89 .

In case of site 5 , it is evident from the table 5 that among emergent macrophytes, Phragmites australis $\left(R_{c}=0.45 ; R_{s}=1.69 ; S=0.569 ; C_{i}=0.431\right)$ and Typha angustata $\left(R_{c}=0.66 ; R_{s}=1.80 ; S=0.605 ; C_{i}=0.395\right)$ were dominant. All the emergent plant varieties showed positive correlation with nitrate $(\mathrm{r}=0.826)$, phosphate $(\mathrm{r}$ $=0.459)$ and Ammonical nitrogen $(\mathrm{r}=0.852)$. Among rooted floating leaf type macrophytes, Nelumbo nucifera $\left(R_{c}=0.42 ; R_{s}=1.82 ; S=0.609 ; C_{i}=0.391\right) ;$ Nymphea maxicana $\left(R_{c}=0.49 ; R_{s}=1.75 ; S=0.609 ; C_{i}=0.391\right)$; Nymphea peltatum $\left(R_{c}=0.49 ; R_{s}=1.74 ; S=0.621 ; C_{i}\right.$ $=0.379)$, and Trapa natans $\left(R_{c}=0.39 ; R_{s}=1.77 ; S=\right.$ $\left.0.621 ; C_{i}=0.379\right)$ were dominant. All the rooted floating leaf type plant varieties showed positive correlation with nitrate $(\mathrm{r}=0.99)$, phosphate $(\mathrm{r}=0.638)$ and Ammonical nitrogen $(r=0.759)$.

Similarly among submerged macrophytes, Ceratophyllum demersum $\left(R_{c}=0.32 ; R_{s}=1.59 ; S=0.613 ; C_{i}=0.387\right)$; Hydrilla verticillata $\left(R_{c}=0.33 ; R_{s}=1.75 ; S=0.621 ; C_{i}=\right.$ $0.379)$; and Myropphyllum spicatum $\left(R_{c}=0.35 ; R_{s}=1.77\right.$; $\left.S=0.621 ; C_{i}=0.379\right)$ were dominant. All the submerged plant varieties showed positive correlation with nitrate $(\mathrm{r}$ $=0.585)$, phosphate $(\mathrm{r}=0.781)$ and Ammonical nitrogen $(\mathrm{r}=0.982)$. Likewise, among free floating macrophytes, Azolla pinnata $\left(R_{c}=0.44 ; R_{s}=1.89 ; S=0.621 ; C_{i}=\right.$ $0.379)$; Lemna spp. $\left(R_{c}=0.42 ; R_{s}=1.82 ; S=0.629 ; C_{i}\right.$ $=0.371)$; and Salvinia natans $\left(R_{c}=0.41 ; R_{s}=1.83 ; S=\right.$ $0.629 ; C_{i}=0.371$ ) were dominant. All the free floating plant varieties showed positive correlation with nitrate $(\mathrm{r}=0.825)$, phosphate $(\mathrm{r}=0.817)$ and Ammonical nitrogen $(r=0.729)$. The strong positive correlation with the chemical constituents of water indicate the highest pollution status of Anchar lake with ESMI of 0.150 and MRI value of 20.22 .

In case of site 6 , it is evident from the table 6 that among emergent macrophytes, Phragmites australis $\left(R_{c}=0.59 ; R_{s}=2.54 ; S=0.712 ; C_{i}=0.288\right)$ and Typha angustata $\left(R_{c}=0.69 ; R_{s}=2.40 ; S=0.716 ; C_{i}=0.284\right)$ were dominant. All the emergent plant varieties showed positive correlation with nitrate $(\mathrm{r}=0.925)$, phosphate $(\mathrm{r}$ $=0.828)$ and Ammonical nitrogen $(\mathrm{r}=0.875)$. Among rooted floating leaf type macrophytes, Nelumbo nucifera $\left(R_{c}=0.65 ; R_{s}=2.45 ; S=0.726 ; C_{i}=0.274\right) ;$ Nymphea maxicana $\left(R_{c}=0.56 ; R_{s}=2.47 ; S=0.721 ; C_{i}=0.279\right)$; Nymphea peltatum $\left(R_{c}=0.59 ; R_{s}=2.41 ; S=0.721 ; C_{i}\right.$ $=0.279)$, and Trapa natans $\left(R_{c}=0.49 ; R_{s}=2.56 ; S=\right.$ $\left.0.769 ; C_{i}=0.231\right)$ were dominant. All the rooted floating leaf type plant varieties showed positive correlation with nitrate $(\mathrm{r}=0.816)$, phosphate $(\mathrm{r}=0.815)$ and Ammonical nitrogen $(r=0.982)$.
Similarly among submerged macrophytes, Ceratophyllum demersum $\left(R_{c}=0.39 ; R_{s}=2.29 ; S=0.729 ; C_{i}=0.271\right)$; Hydrilla verticillata $\left(R_{c}=0.39 ; R_{s}=2.65 ; S=0.756 ; C_{i}=\right.$ $0.244)$; and Myropphyllum spicatum $\left(R_{c}=0.39 ; R_{s}=2.38\right.$; $S=0.752 ; C_{i}=0.248$ ) were dominant. All the submerged plant varieties showed positive correlation with nitrate ( $\mathrm{r}$ $=0.498)$, phosphate $(\mathrm{r}=0.852)$ and Ammonical nitrogen $(\mathrm{r}=0.569)$. Likewise, among free floating macrophytes, Azolla pinnata $\left(R_{c}=0.51 ; R_{s}=2.21 ; S=0.755 ; C_{i}=\right.$ $0.245)$; Lemna spp. $\left(R_{c}=0.53 ; R_{s}=2.28 ; S=0.762 ; C_{i}\right.$ $=0.238)$; and Salvinia natans $\left(R_{c}=0.52 ; R_{s}=2.29 ; S=\right.$ $\left.0.692 ; C_{i}=0.308\right)$ were dominant. All the free floating plant varieties showed positive correlation with nitrate $(\mathrm{r}=0.598)$, phosphate $(\mathrm{r}=0.489)$ and Ammonical nitrogen $(r=0.579)$. The strong positive correlation with the chemical constituents of water indicate the highest pollution status of Anchar lake with ESMI of 0.150 and MRI value of 25.20.

\section{Discussion}

For over two decades, aquatic biologists have been developing biotic indicators of ecosystem health, seeking to identify biological measures that function over a wide geographic region, while displaying a sensitive and consistent response to specific anthropogenic stresses. Initially these studies focused in fish and invertebrates to develop widely applicable measures of stream health. Zutshi et al., (1980), Kaul and Handoo (1980) and Pandit (2002b) made extensive studies on various forms of aquatic plants in Kashmir lakes and found profuse growth of emergents to be indicative of productive nature of the lake water.

Aquatic Macrophytic species were studied in three lakes of Jhansi, Bundelkhand region by Sheikh et al., (2011). The authors reported 10 species belonging to 9 families from the lakes. The frequency values evaluated for various species were: 0.84 for Eichhornia crassipes; 0.72 for Ipomea aquatica; 0.53 for Elatina triandra; 0.26 for Potamogeton pectinatus and 0.28 Amaranthus virdis. The maximum values for density were recorded for Eichhornia crassipes (0.47), Ipomea aquatica (0.47), and Potamogeton pectinatus (0.47), whilst mimimum density values were recorded for Potamogeton pectinatus (0.05). The maximum contribution to IVI (Importance Value Index) was recorded for the species like Ipomea aquatica (111.96), Eichornia crassipes (99.56) and lowest values were recorded for the Species like Parthenium hystrophorus (21.96) and Phalaris arundinaceae (25.02). All the studied lakes were having greater coverage of emergent macrophytes indicating that lakes are evolving at rapid pace, owing to change in water quality, water level fluctuation and swallowing of lakes by sedimentation. YThe findings of the above authors lend complete support to our findings.

The authors reported that the floating species like Hydrilla 
spp. and Lemna spp. were dominant among floating plants, Nymphea spp. and Nelumbo spp. among rooted floating species, Ceratophyllum demersum and Utricularia spp. among sub-merged macrophytes, which correlates with the present finding. The results obtained during the present research tenure get support from the findings of Dhote \& Dixit (2007), Mandal et al., (2010), Raju et al., (2010), Udayakumar et al., (2010), Thangadurai et al., (2012), Saravana (2013), Dana Ahmed \& Mohammed Barznji (2014), Jyothi et al., (2014) and Kiran (2015). During the present research work, the macrophytic abundance was observed in coherence with the nutrient enrichment in the respective regions, which gets complete support from the findings of the authors enlisted.

\section{REFERENCES}

Azzella, M., Rosati, L., Iberite, M., Bolpagni, R. \& Blasi, C. (2014): Changes in aquatic plants in the Italian volcanic-lake system detected using current data and historical records. Aquat. Bot. 112: 41-47.

Bresciani, M., Bolpagni, R., Braga, F., Oggioni, A. \& Giardino, C. (2012): Retrospective assessment of macrophytic communities in southern Lake Garda (Italy) from in situ and MIVIS (Multispectral Infrared and Visible Imaging Spectrometer) data. $J$. Limnol. 71: 180-190.

Carr, J., D'Odorico, P., McGlathery, K. \& Wiberg, P. (2010): Stability and bistability of seagrass ecosystems in shallow coastal lagoons: Role of feedbacks with sediment resuspension and light attenuation. $J$. Geophys. Res. 115: G03011,

Dana Ahmed Mohammed Barznji (2014): Role of Aquatic Plants in Improving Water Quality. UJPBS. 02(05): 12-16.

Dhote S, Dixit S. (2007): Water quality improvement through macrophytes. A case study. Asian J Env Sci. 21(2): 427-430.

Duarte, C. M., Middelburg, J. J. \& Caraco, N. F. (2005): Major role of marine vegetation on the oceanic carbon cycle. Biogeosciences. 2: 1-8.

Hicks, A. L. \& Frost, P. C. (2011): Shifts in aquatic macrophyte abundance and community composition in cottage developed lakes of the Canadian Shield. Aquat. Bot. 94: 9-16.

JAVID, A SHEIKH, G. JELLANI \& R.S. GAVALI (2011) Distribution of emergent macrophytes of three eutrophic lakes form Jhansi, Bundelkhand region. $J$. Res. and Deve., Vol. 11: 41-48.

Jyothi PV, Sureshkumar S. (2014): Preliminary documentation of aquatic Macrophytes of Kole wetlands of Northern Kerala, India. International Journal of Environmental Sciences. 1(5): 117-122.

Kaul, V., Handoo, J.K. and Raina, R. (1980): Proceedings of Indian Natural Science Academy. 46(4): 528-541.

Kiran BR. (2015): Distribution and Diversity of Aquatic Macrophytes in Jannapura Tank of Bhadravathi Taluk, Karnataka. International Journal of Plant, Animal and Environmental Sciences. 5(2).

Krause-Jensen, D., Sagert, S., Schubert, H. \& Boström, C. (2008): Empirical relationships linking distribution and abundance of marine vegetation to eutrophication. Ecol. Indic. 8: 515-529.

Lawrence, W. R. (1895) The valley of Kashmir. Chinar Publishing House, Srinagar, Kashmir.

Mandal RN, Datta AK, Sarangi N, Mukhopadhya PK. (2010): Diversity of aquatic macrophytes as food and feed components to herbivorous fish - a review. Indian $J$ Fish. 57(3): 65-73.

Orth, R. J. et al., (2006): A global crisis for seagrass ecosystems. Bioscience. 56: 987-996.

Pandit, A.K. (2002), Trophic evolution of lakes in Kashmir Himalaya. p. 175-222. In: Natural Resources of Western Himalaya, Edited by A. K. Pandit (Valley Book House, Srinagar-190006, J\&K).

Qin, B. (2008): Lake Taihu, China: Dynamics and Environmental Change. 87 (Springer Science \& Business Media).

Qin, B., Xu, P., Wu, Q., Luo, L. \& Zhang, Y. (2007): Environmental issues of Lake Taihu, China. Hydrobiologia. 581: 3-14.

Raju AR, Anitha CT, Sidhimol PD, Rosna KJ. (2010): Phytoremediation of domestic waste water by using a free floating aquatic angiosperm, Lemna minor. Nat. Environ, and Pollu. Tech. (9)1: 83-88.

Saravana kumar, Prabhakaran. (2013): Aquatic floral populations in Veeranam lake command area, Tamil Nadu, India. International Journal of Current Biotechnology.

Schallenberg, M. \& Sorrell, B. (2009): Regime shifts between clear and turbid water in New Zealand lakes: environmental correlates and implications for management and restoration. New Zeal. J. Mar. and Fresh. 43: 701-712.

Scheffer, M., Carpenter, S., Foley, J. A., Folke, C. \& Walker, B. (2001): Catastrophic shifts in ecosystems. Nature. 413: 591-596. 
Søndergaard, M. et al., (2010): Submerged macrophytes as indicators of the ecological quality of lakes. Freshwater Biol. 55: 893-908.

Thangadurai RT, Ravi Mycin M Lenin, Devasena T. (2012): Aquatic macrophytes in Veeranam tank, Cuddalore District (India). Int J Curr Sci. 3: 67-71.

Udayakumar M, Ajithadoss K. (2010): Angiosperms, Hydrophytes of five ephemeral lakes of Thiruvallur District, Tamil Nadu, India. Checklist. 6(2): 270-74.
Villamagna, A. \& Murphy, B. (2010): Ecological and socioeconomic impacts of invasive water hyacinth (Eichhornia crassipes): a review. Freshwater Biol. 55: 282-298.

Waycott, M. et al., (2009): Accelerating loss of seagrasses across the globe threatens coastal ecosystems. $P$. Natl. Acad. Sci. USA 106, 12377-12381.

Zutshi, D.P., Subla, B.A., Khan, M.A., and Wanganeo, A. (1980): Comparative Limnology of nine lakes of Jammu and Kashmir, Himalaya, Hydrobiologia. 72 : 101 - 112 . 